\title{
Petrography and Geochemistry of Rocks of Northern Part of Wonaka Schist Belt, Northwestern Nigeria
}

\author{
${ }^{1} \mathrm{M}$. A. Usman and ${ }^{2}$ A.A. Ibrahim \\ ${ }^{1}$ Federal Road Safety Commission RS 1.13 Zaria Unit Command, Nigeria \\ 2Department of Geology, Ahmadu Bello University, Zaria \\ [Corresponding Author: Email: alikazy@icloud.com; D: +2348065667270]
}

\section{ABSTRACT}

Systematic mapping and sampling of rocks of northern part of Wonaka schist belt on a scale of 1:50,000 shows that the belt is composed of gneiss, granite gneiss, muscovite-biotite schist, banded iron formation, amphibolite, granite, granodiorite and diorite as major rock types, other rocks are aplite, and pegmatite. Petrographic and geochemical data shows that the there are two types of gneisses in the area: the orthogneiss and the paragneiss. Plots of $\mathrm{TiO}_{2}$ vs $\mathrm{SiO}_{2}$ shows that the granite gneiss is paragneiss while the gneiss is an orthogneiss. The granites and the granodiorite are I - Type and the amphibolite is volcaniclastic. The banded iron formation (BIF) is shown to be hematite facies type from a plot of $\mathrm{MnO}_{\mathrm{vs}} \mathrm{FeO}_{(\mathrm{T})}$. It can therefore be said that the orthogneiss represents the original basement rock possibly dating back to the early phase of the Eburnean orogeny. At later stages of the Eburnean, sedimentary deposition and subsequent metamorphism of the sediments might have led to the formation of the paragneiss and the metasediments with the associated BIF as indicated by the REE distribution pattern. The NNE - SSW and the $\mathrm{N}-\mathrm{S}$ structural trends on the rocks might have been developed by the over printing effects of the PanAfrican orogeny

Keywords: orthogneiss, schist belt, paragneiss, banded iron formation, metasediments

\section{INTRODUCTION}

The Wonaka schist belt is one of the 13 schist belts identified within the Nigerian basement complex. It is located about $35 \mathrm{Km}$ east of Maru schist belt and about $150 \mathrm{~km}$ west of Kazaure schist belt. Most of the belt is within Sheets 54 (Gusau), 77 (Chafe) and 78 (Faskari).

The earliest work on Wonaka schist belt was by McCurry (1973) who reported that the belt is situated northwest of Karaukarau belt with a major N-S rock orientation trend. The work showed that petrographically, Wonaka schist belt is composed of fine grained quartz-biotite rocks that locally contain sillimanite, cordierite or garnet. Thin beds of calc-silicate rocks are widely distributed in the western part while biotitemuscovite schist, quartzites, ferruginous schist, gneisses and mylonites constitute the lithology of reminder of the belt. The work also shows that metamorphism in Wonaka schist is of higher temperature and lower pressure type than in other schist belts. This could be due to the close association with large batholithic masses of granite and granodiorite which almost engulf the Wonaka schist belt. Harper et al. (1973) showed that Wonaka and Karau-karau schist belts have similar age of formation. K-Ar ages for whole rocks and biotite range from 515 to $550 \mathrm{Ma}$ and represents cooling ages at Karau-karau. Turner (1984) reported that the rocks of Wonaka schist belt are mudstones and marls; the work also showed that westward of Kazaure belt, through the Karau-karau to the Wonaka belt, the amount of course grained clastics is progressively reduced. The three belts may therefore contain different facies of one sedimentary basin.

Woakes and Bafor (1984) reported that primary gold deposits are associated with some schist belts (e.g. llesha, Maru, Anka, Kushaka) and not with others (Wonaka, Karau-karau, Iseyi-Ogun River), and that they are often spatially related to amphibolites and regional NE-SW to N-S fault or shear zones and devoid of Banded Iron Formation (BIF). 
However, these works were all carried out on regional scale or part of an exploration work for some targeted mineral resources. None of the works was dedicated to the study of petrography and geochemistry of the rocks in the belt, which are key studies that defines the geology of an area.

In this paper we present the petrography and geochemistry of rocks in the Wonaka schist belt with a view to determining the mode of evolution of the rocks.

\section{GEOLOGICAL BACKGROUND}

The Nigerian basement complex rocks form part of the rejuvenated Dahomeyan rocks situated between the West African and Congo Cratons and belongs to the Pan African mobile belt (c. $600 \mathrm{Ma}$ ) that have been correlated with the Boborema province of Brazil (Caby, 1989; Dada, 2008 and Goki et al., 2010). The basement complex is composed of three broad groups of rocks.

i.) The Migmatite-Gneiss Complex or Basement Complex (sensu stricto) is composed of gneisses and migmatites with entrained supracrustal relics whose metamorphism is generally in the amphibolites facies grade. Other, but relatively minor rocks are mainly amphibolites, calcareous rocks, and pegmatites (Wright et al., 1985; Dada, 1999). Rock ages range from Archaean to Upper Proterozoic, generally overprinted by the Pan African event $(750-450 \mathrm{Ma})$.

ii.) The Nigerian schist belts occur in a 300 to 400 $\mathrm{km}$ wide NNE trending zone, which can be traced along strike for about $800 \mathrm{~km}$ predominantly west of longitude $8{ }^{\circ} \mathrm{E}$; and are apparently infolded into the Migmatite-Gneiss Complex. Lithologically, the schist belts are composed predominantly of pelitic and semi-pelitic schists, with intercalated quartzites, Banded Iron Formation (BIF), calcsilicate rocks and marbles as well as basic to acid meta-volcanics. Basement-cover relationship is still disputed, and even the distinction from the basement sensu strictu is not always clear (Trompette, 1994). Radiometric dates strongly testify to penetrative Pan-African event, but some of the schist belts may be of Birrimian age (Paleoproterozoic) or older (Turner, 1983; Fitches et al., 1985; Ajibade et al., 1987; Trompette, 1994; Adekoya, 1996; Dada, 1999).

iii.) The Older Granites of Nigeria occur in all parts of the Nigerian basement (Ajibade et al., 1987). The Older Granites intrude into the gneiss-migmatite (Dahomeyan), and the schist belts and were emplaced by stopping and diapiric processes (Fitches et al., 1985). They are generally regarded as syn to post-tectonic with respect to the main deformation of the PanAfrican tectonism.

\section{MATERIALS AND METHODS}

The field work was carried out using compass traverse and also following river and stream courses on a scale of 1:50,000. Systematic sample of the component rock types was concurrently conducted with about $2 \mathrm{~kg}$ of fresh samples of each of the major rock types collected, using sledge and geological hammer. The accurate location while mapping and sample collection was determined using Global Positioning System (GPS). Thin and polished sections of the rocks were produced at the Department of Geology, Ahmadu Bello University, Zaria. The geochemical analysis was carried out at the ACT Labs Ontario, Canada using Inductively Coupled Plasma Mass Spectrometry and at the Department of Geology Kano University of Science and Technology using X - Ray Florescence analysis. Flame Photometry analyses for the same rock samples was carried out at the Centre for Energy Research and Training (CERT), Ahmadu Bello University Zaria for the determination of alkalis. The analysis produced results for major, trace and rare earth elements. The data obtained was interpreted using the geochemical data tool kit (GCD Toolkit 3.0) software. 


\section{RESULTS AND DISCUSSION}

\section{Lithology and field relationship}

The Wonaka schist belt comprises of the following rock types; granite gneiss, biotite muscovite schist, greenstone, granodiorite, hornfels, and granite as major rocks while banded iron formation, aplite dyke and pegmatite occur as minor rocks (Figure 6)

\section{Granite Gneiss}

This rock type is best exposed at a road cut in Kwatarkoshi town, along the main road leading to Gusau, the capital of Zamfara State. It marks the western boundary of the schist belt, here, the gneissic rock occurs as an elevated ridge with an average altitude of about 2,100m above mean sea level. The ridge extends along a NNE - SSW trend following the northern and western part of the town. Locally, the rock exhibits conspicuous banding that trends N-S. The color of the rock varies from grey to pink. The rock body extends up to the end of the northern boundary of the study area, where it is bounded by a granodiorite at the northeastern part of the study area around Butsa. To the east, it is bounded by diorite

\section{A}

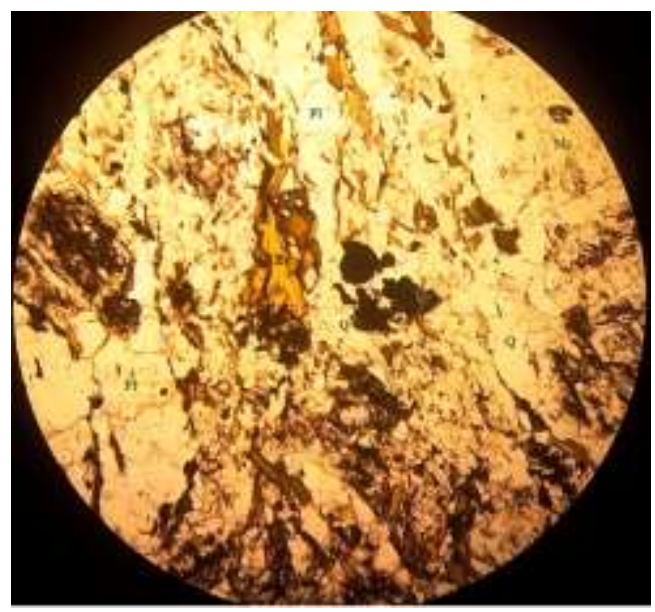

around Mada town and to the south, contact with the biotite-muscovite schist.

At the top of ridge, the rock is granitic, while the lower parts of the ridge are gneissic in composition. Structural feature such as quartz veins, joints and foliation all have a general N-S orientation. Quartz veins are of various sizes averaging $27 \mathrm{~cm}$ wide and $20 \mathrm{~m}$ long. The texture of the rock varies from fine-grained, medium-grained to porphyritic.

In thin section, the sample shows both foliation and lineation of the component minerals. The rock is generally medium grained with quartz as the most abundant mineral (about 40\%). The quartz is subhedral and colorless with the characteristic wavy extinction. Biotite crystals are brown in color with distinct one directional cleavage (Figure 1). The biotite constitutes about $35 \%$ of the rock. Plagioclase feldspars constitute about $20 \%$ of the rock. Other minerals include orthoclase feldspars and muscovite in minor quantities.

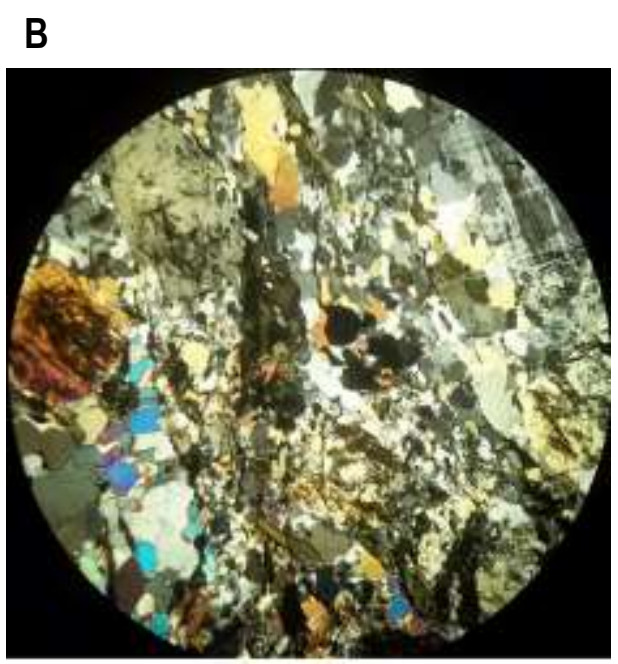

Figure 1: Photomicrograph of granite gneiss in A ppl and B xpl. Foliation is defined by the sub parallel arrangements $\mathrm{Bt}$ - biotite, lineation defined by the feldspars: PI - plagioclase and $\mathrm{Mc}$ - microcline. Other minerals are $\mathrm{Qz}$ - quartz and iron oxide as opaque 


\section{Biotite - Muscovite Schist}

It is dark brown in color and foliated. The schist is silicified and interbedded with thin layers of carbonaceous schist. It trends in N-S direction.

In hand specimen the rock is fine-grained, dark colored with clear whitish bands. It is composed of muscovite, biotite and feldspars. Under the microscope biotite crystals arranged in parallel to sub parallel planer pattern, defines the foliation. The biotite is brown with straight extinction and one directional cleavage. It is about $60 \%$ of the rock (visual estimation). Muscovite is pleochroic from pinkish to pale white and constitutes about $25 \%$ of the rock (visual estimation). Quartz is colorless with distinct wavy extinction, about $5 \%$ of the rock (Figure 2).

\section{Amphibolite}

The greenstone is located at Biya-Buki, N 12० 02' $059^{\prime \prime}$ and $E 006^{\circ} 50.4^{\prime}$. The rock occurs as low lying outcrop. It is devoid of structures such as quartz veins, joints and xenoliths. The rock body trends in the general $\mathrm{N}-\mathrm{S}$ directional trend.

The rock is massive to weakly foliated and dark green in color. It is composed of dark green glassy crystals and white subhedral quartz crystal with a general fine grained texture. The

A

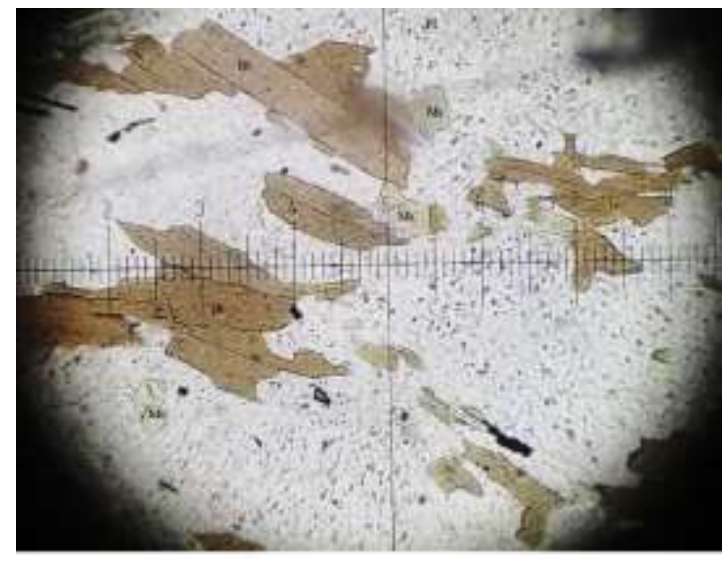

rock has sharp edges and is heavy in hand specimen.

In plane polarized light, the rock is non-foliated and fine grained plagioclase feldspars occur as subhedral exhibiting albite twinning, constitutes about $30 \%$ of the rock. Quartz crystals are yellowish in color and granular and are about $30 \%$ of the rock. Light greenish crystals of amphibole (actinolite) are observed in PPL, with some opaque minerals and constitute about $40 \%$ of the rock.

\section{Banded iron formation (BIF)}

In the central parts of the study area, is an N-S trending and extensive ferruginized metasedimentary ridge containing banded iron formation. The metasedimentary ridge is composed of schist and phyllite interlayered with BIF. The BIF form the "spine" of the ridge. The BIF is highly weathered and well exposed on the metasedimentary ridge (Figure 1). At $11057^{\prime} 08^{\prime \prime} \mathrm{N}$ and $006^{\circ} 53^{\prime} 46^{\prime \prime} \mathrm{E}$, five kilometers southwards of the School of Health Technology, Chafe, Zamfara State, Nigeria, the metasedimentary ridge containing the BIF makes a contact with the granite at Chafe. In hand specimen, the BIF is dark reddish brown, banded

B

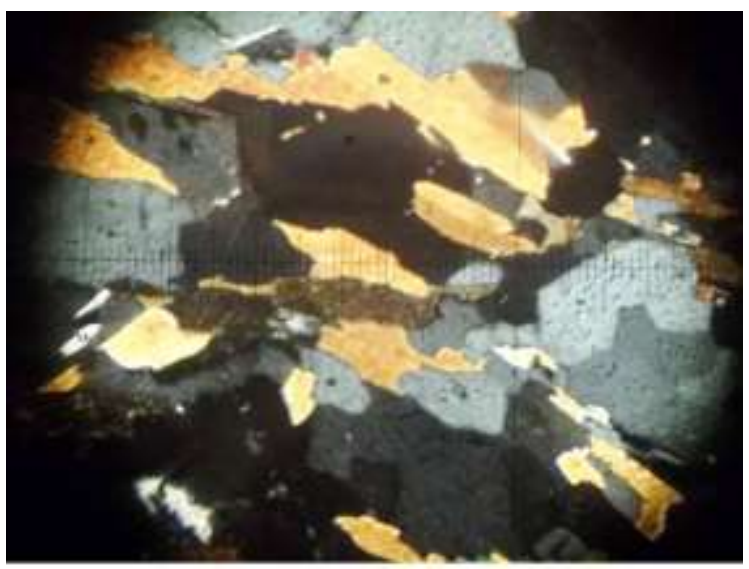

Figure 2: Biotite - muscovite schist showing a) in ppl biotite - $\mathrm{Bt}$, plagioclase - $\mathrm{Pl}$, muscovite - Ms and b) xpl granular, foliated fabric of the rock is presented. 
rock with alternation of light grey rich silica and darker iron-oxide rich bands. It is the homogeneous variety and occurs as boulders of different sizes. Texturally, the BIF is fine-grained.

In reflected light it is equigranular and shows distinctive alternation of hematite and manganese crystals. The hematite crystal shows high reflectance with a granoblastic texture. It is about $50 \%$ (visual estimation) of the rock. The manganese crystals are greenish in color in plane polarized light and constitute about 35\% (visual estimation) of the rock. Quartz constitutes about $10 \%$ of the rock.

\section{Granite}

This rock occurs mostly in the extreme south eastern part of the study area, around Magazu town north of Chafe as whale back exposures and as a ridge. The granite is light grayish in color with N-S orientation. Boulders of mediumgrained biotite granite were observed at the foot of the outcrop. The granite is in form of a ridge and rise to an average altitude of $1,850 \mathrm{~m}$, the major road leading to Gusau from Funtua cuts through this rock. The granite extends up to the end of the southern boundary o the study area at Magazu town. The rock is well jointed mostly in $\mathrm{N}-\mathrm{S}$ direction. The texture of the granite varies from medium, course to porphyritic. In thin

\section{A}

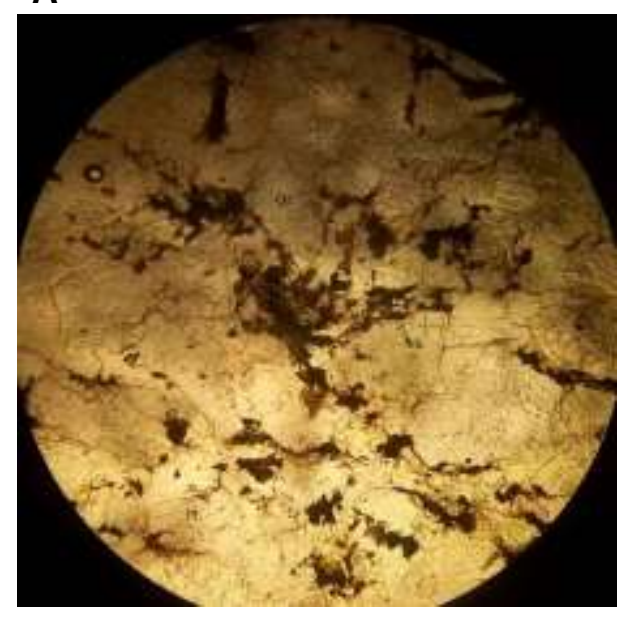

section, the rock contains quartz, feldspar and biotite. Quartz is the most abundant mineral, about 35\% (visual estimation). It is anhedral and colorless. Biotite is brown with its distinct one directional cleavage and constitutes about 30\% of the rock. Microcline exhibiting cross-hatched twinning is about $20 \%$ of the rock. Plagioclase feldspar is about $5 \%$ (Figure 3 ).

\section{Granodiorite}

This occurs at the northeastern part of the study area around Koha and Butsa villages. It occurs as low lying outcrops and boulders, with NE-SW trend. The rock makes a boundary with the granitic gneiss at the southwest and diorite to the south and medium grained granite to the north east.

The rock is non-foliated and fine grained in plane polarized light. Plagioclase feldspar is the most abundant mineral present. It constitutes about $55 \%$ of the rock (visual estimation). Quartz crystals are colorless and up to about $15 \%$ of the rock. Biotite 10\%, hornblende 10\%, grunerite 3\% and opaque minerals accessory minerals constitute about $7 \%$ of the rock.

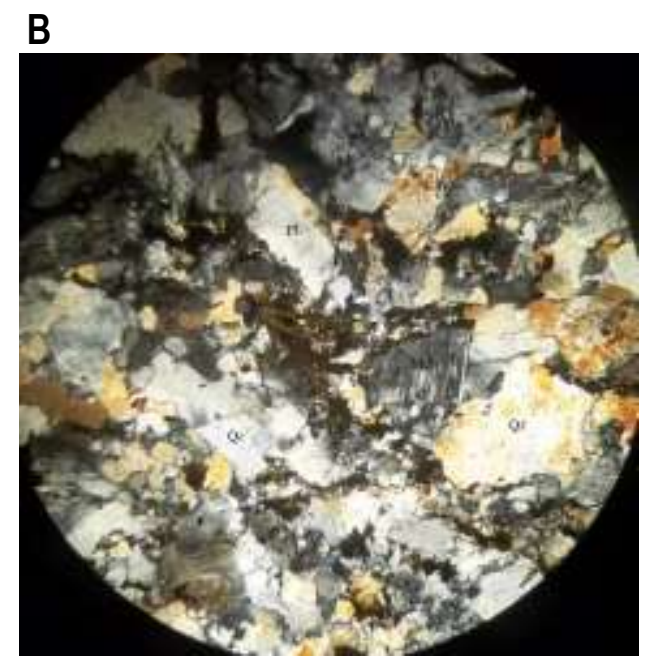

Figure 3: A) Ppl micrograph of granite with quartz - Qz, plgiclase - PI, biotite - Bt, and microcline - Mc. B) the xpl micrograh showing the granular and non foliated character of the rock. 
A

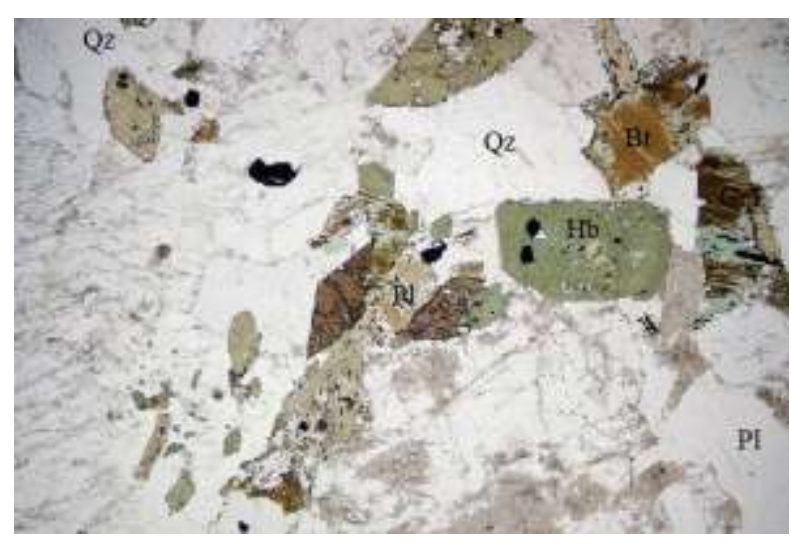

B

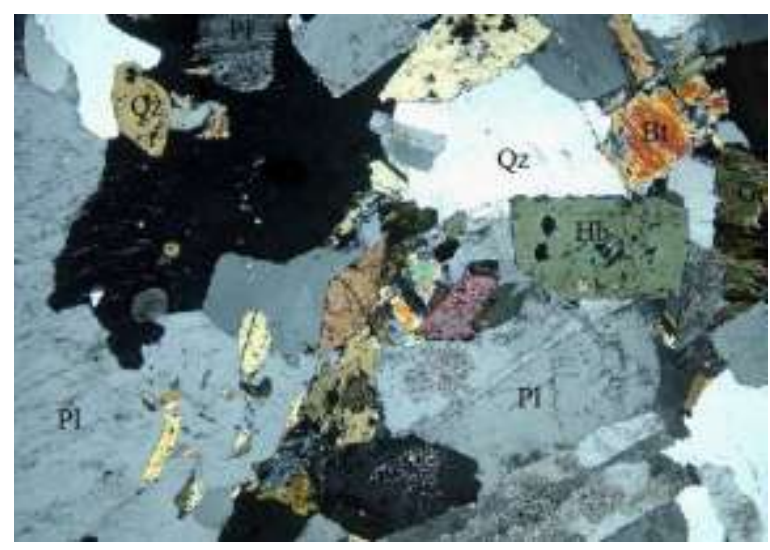

Figure 4: Photomicrograph of granodiorite showing the granular intergrowth of plagioclase $-\mathrm{PI}, \mathrm{Qz}-\mathrm{Qz}$, biotite - Bt, hornblende - $\mathrm{Hb}$ and grunerite - GrT; a) ppl, b) xpl.

Hornfels:

The hornfels occurs in TudunWada at the central parts of the mapped area. It occurs as a low-lying dome shaped outcrop. It is light grey to pink in color and about $500 \mathrm{~m}$ long and $500 \mathrm{~m}$ wide with $\mathrm{N}-\mathrm{S}$ orientation. Numerous joints and quartz veins are observed on the outcrop, defining the two dominant fracture patterns in the area, $\mathrm{N}-\mathrm{S}$ and $\mathrm{E}-\mathrm{W}$. The rock is fine- grained in texture. In thin section, the rock is non-foliated. It is equigranular. The hornblende (actinolite) occurs as needle like with a perfect two directional cleavages and dark brown. It shows pleochroism from brownish to greenish. It constitutes about $30 \%$ (visual estimation) of the rock. Plagioclase feldspars are subhedral with light brown color; it is about 15\% (visual estimation). Quartz crystals are colorless with wavy extinction, and constitute about $5 \%$ of the minerals that make up the rock. Rounded almandine garnet crystals are about $5 \%$. Tourmaline as acicular or needle-like crystals is present, brown and elongated. It is pleochroic from brown to dark brown with weak cleavage. It is about 45\% (visual estimation).

\section{Aplite dyke and pegmatite}

Aplite dykes occur in granite, diorite and granodiorite in the area. A prominent aplite dyke cut a diorite exposure around Mada, in the northern part of the study area. Here, the dyke occurs together with a pegmatite and are similar in mineralogy differentiated only on the basis of grain size. A fault with dextral sense of displacement of $50 \mathrm{~cm}$ cut the aplite dyke.

\section{GEOCHEMISTRY}

Results of the geochemical analyses are presented in Tables 1 and 2 . The major elements composition shows that the rocks are characterized by high $\mathrm{SiO}_{2}$ in the range of 50.29 84.03 wt $\%$ with an average of $60.77 \mathrm{wt} \%$, low content of $\mathrm{Fe}_{2} \mathrm{O}_{3}(0.81-6.29$ wt \%) with the lowest content in the granite gneiss, and the highest content in the BIF (41.62 wt \%). In addition, $\mathrm{Na}_{2} \mathrm{O}$ remains consistently less than $\mathrm{K}_{2} \mathrm{O}$ in almost all the rock types except in hornfels Table 1. 


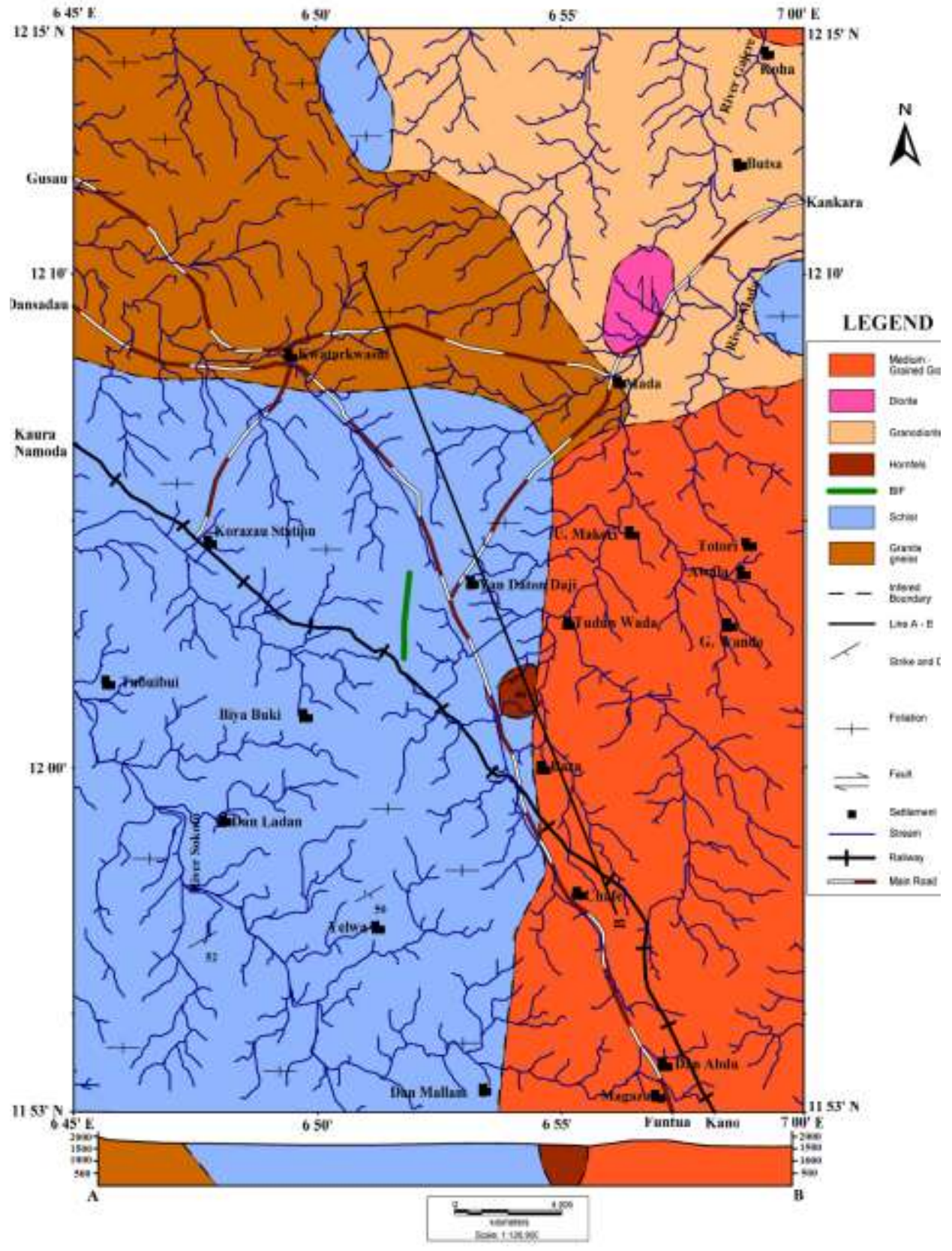

Figure 5: Geological map of northern part of Wonaka schist belt.

Alumina $\left(\mathrm{Al}_{2} \mathrm{O}_{3}\right)$ contents for all the rock types are generally within the range of (5.29-16.70 wt $\%$ ). This values falls within the average continental contents of these rocks. Also, the rocks have aluminum saturation index (defined as the molar ratio of $\mathrm{Al}_{2} \mathrm{O}_{3} /\left(\mathrm{CaO}+\mathrm{Na}_{2} \mathrm{O}+\mathrm{K}_{2} \mathrm{O}\right)$ after Ekwume (2003)) greater than one and consequently falls within the corundum norm except for the hornfels with $\mathrm{Al}_{2} \mathrm{O}_{3}$ l
$\left(\mathrm{CaO}+\mathrm{Na}_{2} \mathrm{O}+\mathrm{K}_{2} \mathrm{O}\right)<1$ probably due to high content of $\mathrm{CaO}$ even greater than $\mathrm{Al}_{2} \mathrm{O}_{3}$, hence cannot have corundum in its norm.

$\mathrm{TiO}_{2}$ and $\mathrm{SiO}_{2}$ composition of the rock samples in the study area were plotted in $\mathrm{TiO}_{2}-\mathrm{SiO}_{2}$ discrimination diagram (Tarney, 1977); in an attempt to determine the nature of their protolith (Figure 6) 


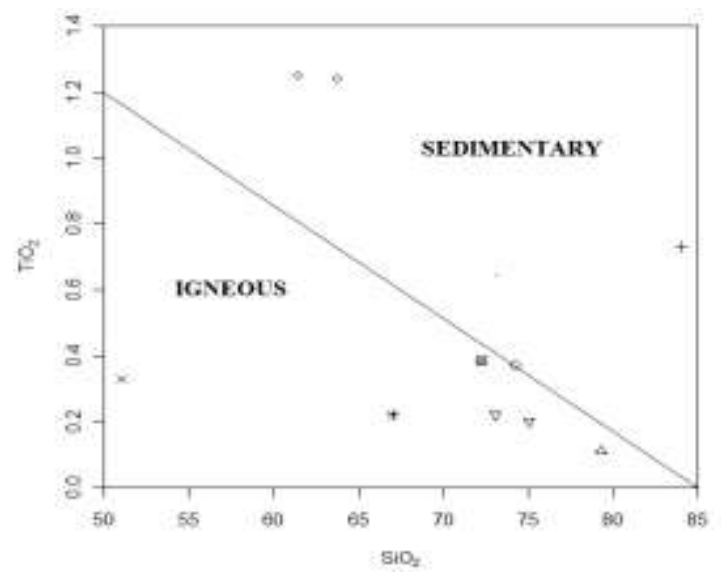

+ Granitic gneiss $\triangle$ Gneiss

- Biotite muscovite schist

$\times$ Hornfels, Greenstone,

$\nabla$ Granodiorite

\section{Medium grained biotite granite}

\section{* Porphyritic granite}

Figure 6: $\mathrm{TiO}_{2}$ versus $\mathrm{SiO}_{2}$ discrimination diagram (after Tarney, 1977). Showing the nature of the protholith of the granitic gneiss, gneiss, biotite muscovite schist, hornfels, amphibolite (greenstone), granodiorite, medium grained biotite granite and porphyritic granite. Line separates sedimentary from igneous protholith.

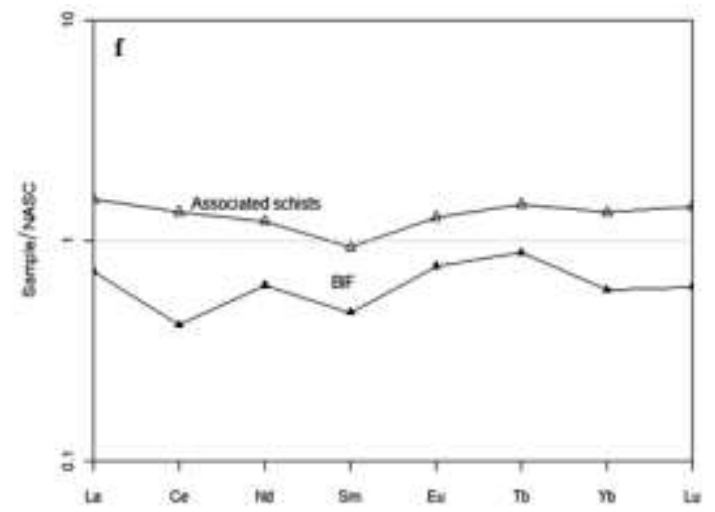

Figure 7. Rare Earth Element distribution pattern of rocks in the area, showing similarity in origin.

From the diagram, granitic gneiss, biotite muscovite schist and greenstone have sedimentary protholiths, while gneiss, hornfels, granodiorite, medium grained biotite granite and porphyritic granite), are from igneous protolith (Figure 7). This shows that the granite gneiss is a paragneiss developed from the prograde metamorphism of schist while the amphibolite represent metamorphosed volcani-clastic sediments within the depositional basin, possibly sourced from a deep ocean volcanic source which could be close to, or from a mid ocean ridge volcano. However from this result derived from the discrimination diagram, there are two types of gneisses in the area, the paragneiss and the orthogneiss. The orthogneiss may represent the older basement, on which the sediments were deposited.

Concentrations of $\mathrm{SiO}_{2}+\mathrm{Al}_{2} \mathrm{O}_{3}$ as well as total elemental concentrations of $(\mathrm{Fe}+\mathrm{Mn})$ in the BIF are comparable to their values in BIF of Unguwar-Malam Ayuba in Malumfashi schist belt that shows a wide range of composition. The $\left(\mathrm{SiO}_{2}+\mathrm{Al}_{2} \mathrm{O}_{3}\right)$ and $\mathrm{Fe}+\mathrm{Mn}$ concentrations of this BIF range from $70-40$ and 40 to $18 \mathrm{wt} \%$ respectively (Mucke et al., 1994). This schist belt is located east of the Wonaka schist belt. The two belts could therefore be regarded to belong to the same sector of the depositional basin, which could explain this similarity in geochemical composition.

Comparison of the chemical composition of the BIFs in the study area with associated rocks and other Nigerian iron-formations with similar settings clearly reveals compositional similarities (Tables 1 and 2). For example, the BIFs have relatively high $\mathrm{Mn}(3.89-5.39 \mathrm{wt} \%), \mathrm{Fe}(39.67-$ $41.62 w t \%)$ and low alkalis $\mathrm{Na}(0.02-0.03 w t \%)$, $\mathrm{K}(0.03-0.04 w \mathrm{wt})$ and $\mathrm{Rb}(5.0-13.0 \mathrm{ppm}) \mathrm{Sr}$ (13-330ppm), Ti (0.69-0.87ppm), Al (5.29$6.71 \mathrm{wt} \%)$ and Si $(50.29-51.21 \mathrm{wt} \%)$ but the associated rocks show opposite in character such as low Mn (0.02-0.08wt\%), Fe ( 0.81-9.52 $\mathrm{wt} \%$ and high alkalis 
Nigerian Journal of Basic and Applied Science (December, 2017), 25(2): 87-99

Table 1: Major elements composition of rocks from the study area (wt \%)

\begin{tabular}{|c|c|c|c|c|c|c|c|c|c|c|c|c|c|c|c|}
\hline $\begin{array}{l}\text { Samples/ } \\
\text { Oxides }\end{array}$ & $\begin{array}{l}\text { MA1 } \\
\text { Granitic } \\
\text { gneiss }\end{array}$ & $\begin{array}{l}\text { MA2 } \\
\text { Granitic } \\
\text { gneiss }\end{array}$ & $\begin{array}{l}\text { MA3 } \\
\text { Granitic } \\
\text { gneiss }\end{array}$ & $\begin{array}{l}\text { MA4 } \\
\text { Biotite } \\
\text { Muscovite } \\
\text { schist }\end{array}$ & $\begin{array}{l}\text { MA5 } \\
\text { Biotite } \\
\text { Muscovite } \\
\text { schist }\end{array}$ & $\begin{array}{l}\text { MA6 } \\
\text { BIF }\end{array}$ & $\begin{array}{l}\text { MA7 } \\
\text { BIF }\end{array}$ & $\begin{array}{l}\text { MA8 } \\
\text { BIF }\end{array}$ & $\begin{array}{l}\text { MA9 } \\
\text { BIF }\end{array}$ & $\begin{array}{l}\text { MA10 } \\
\text { Hornfels }\end{array}$ & $\begin{array}{l}\text { MA11 } \\
\text { amphibolite }\end{array}$ & $\begin{array}{l}\text { MA12 } \\
\text { Granodiorite }\end{array}$ & $\begin{array}{l}\text { MA13 } \\
\text { Granodiorite }\end{array}$ & $\begin{array}{l}\text { MA14 } \\
\text { Granite }\end{array}$ & $\begin{array}{l}\text { MA15 } \\
\text { Granite }\end{array}$ \\
\hline $\mathrm{SiO}_{2}$ & 80.00 & 78.12 & 79.32 & 61.42 & 63.73 & 50.25 & 50.09 & 50.21 & 50.29 & 51.03 & 71.24 & 75.05 & 73.04 & 72.86 & 71.01 \\
\hline $\mathrm{Al}_{2} \mathrm{O}_{3}$ & 12.01 & 12.37 & 12.31 & 14.89 & 14.38 & 4.29 & 4.11 & 3.71 & 3.38 & 14.05 & 13.46 & 16.70 & 15.67 & 13.98 & 13.00 \\
\hline $\mathrm{Fe}_{2} \mathrm{O}_{3} \mathrm{~T}$ & 0.81 & 1.38 & 1.44 & 9.52 & 9.68 & 39.62 & 39.00 & 39.50 & 39.56 & 17.41 & 3.94 & 2.12 & 5.27 & 2.48 & 6.29 \\
\hline $\mathrm{CaO}$ & 0.91 & 0.79 & 1.02 & 0.96 & 0.81 & 0.48 & 0.52 & 0.42 & 0.27 & 15.67 & 2.83 & 0.02 & 0.03 & 2.04 & 1.11 \\
\hline $\mathrm{Na}_{2} \mathrm{O}$ & 0.10 & 0.12 & 0.06 & 0.42 & 0.39 & 0.02 & 0.02 & 0.03 & 0.03 & 0.28 & 0.22 & 2.07 & 1.06 & 0.10 & 0.20 \\
\hline $\mathrm{K}_{2} \mathrm{O}$ & 4.40 & 4.35 & 4.04 & 9.36 & 8.26 & 0.03 & 0.03 & 0.04 & 0.04 & 0.08 & 6.34 & 2.97 & 2.82 & 5.08 & 5.84 \\
\hline $\mathrm{TiO}_{2}$ & 0.73 & 0.63 & 0.29 & 1.25 & 1.24 & 0.87 & 0.76 & 0.83 & 0.69 & 0.33 & 0.51 & 0.20 & 0.22 & 0.43 & 0.22 \\
\hline $\mathrm{MgO}$ & 0.90 & 1.90 & 0.98 & 3.83 & 2.74 & 0.61 & 0.64 & 0.58 & 0.59 & 0.61 & 8.00 & 0.52 & 0.56 & 1.04 & 1.00 \\
\hline $\mathrm{MnO}$ & 0.02 & 0.03 & 0.08 & 0.54 & 0.43 & 4.37 & 4.53 & 3.89 & 4.39 & 0.14 & 0.06 & 0.05 & 0.06 & 0.04 & 0.16 \\
\hline $\mathrm{P}_{2} \mathrm{O}_{5}$ & 0.08 & 0.12 & 0.11 & 0.70 & 0.10 & 0.01 & 0.09 & 0.17 & 0.13 & 1.23 & 0.17 & 0.08 & 0.99 & 0.12 & 0.11 \\
\hline TOTAL & 99.97 & 99.81 & 99.65 & 99.36 & 99.42 & 99.93 & 99.37 & 99.28 & 99.78 & 98.99 & 98.60 & 99.78 & 99.72 & 99.17 & 92.86 \\
\hline
\end{tabular}




\section{Usman and Ibrahim: Petrography and Geochemistry of Rocks of Northern Part of Wonaka Schist.....}

Table 2. Trace element composition of rocks in the study area (ppm)

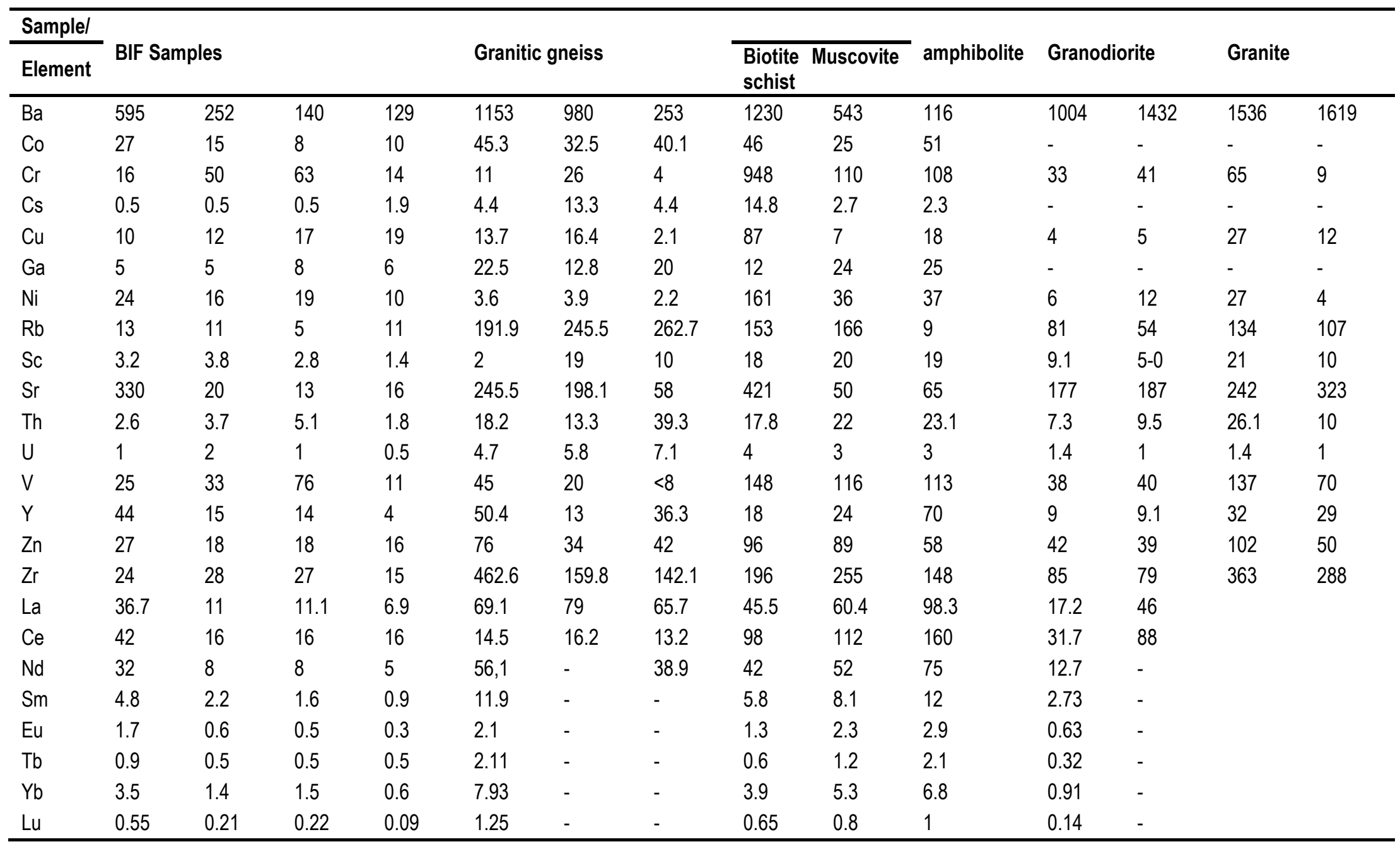


$\mathrm{Na}$ (average of $0.06-0.42 \mathrm{wt} \%), \mathrm{K}(0.08-$ $9.36 \mathrm{wt} \%), \mathrm{Rb}(9.0-262.7 \mathrm{ppm}), \mathrm{Sr}(65-323$ ppm), Ti (0.22-1.24wt\%), Al (11.98 - 16.70 $w t \%)$, Si $(61.42-84.03 w t \%)$. These values are comparable to the values of other northern Nigeria iron-formations such as that of BirninGwari with high Mn (5.98 wt \%), Fe (42.84 wt\%), Al $(7.93 \mathrm{wt} \%), \mathrm{Si}(50.59 \mathrm{wt} \%)$, alkalis $\mathrm{Na}$ $(0.02 w t \%), K(0.04 w t \%)$ except for $\mathrm{Rb}$ and $\mathrm{Sr}$ that shows a slight variations of $(1.1 \mathrm{ppm}$ and 48ppm) respectively (Mucke et al., 1996). This dissimilarity in chemical compositions between the BIF and the associated rocks clearly suggest difference in sources of the material for the formation of the BIF and the associated rocks.

The high amount of $\mathrm{Fe}$ and $\mathrm{Mn}$ in the BIF may be as a result of supergene enrichment in the ironformation, as envisaged by Adekoya, (1996), who showed that the $\mathrm{Mn}$ is enriched in the oxide facies iron formation of Nigeria from $1.4 \%$ to $4.5 \%$ and the $\mathrm{Fe}$ enriched from $25 \%$ to $35 \%$. This is as a result of repeated leaching and redeposition of $\mathrm{Fe}$ and $\mathrm{Mn}$ oxide within the enrichment zone.

When $\mathrm{MnO}$ and $\mathrm{FeO}(\mathrm{T})$ of the $\mathrm{BIF}$ are plotted (Figure 8) it shows that the BIF in the study area belongs to the hematite facies BIF. The high Mn content of the BIF is as a result of the effect of the interlayered manganese layers closely associated the BIF within the sedimentary sequence, this is in agreement with Mucke (2005) who showed that the Nigeria BIFs are characterized by high manganese concentrations unlike many other BIFs with similar mode of origin.

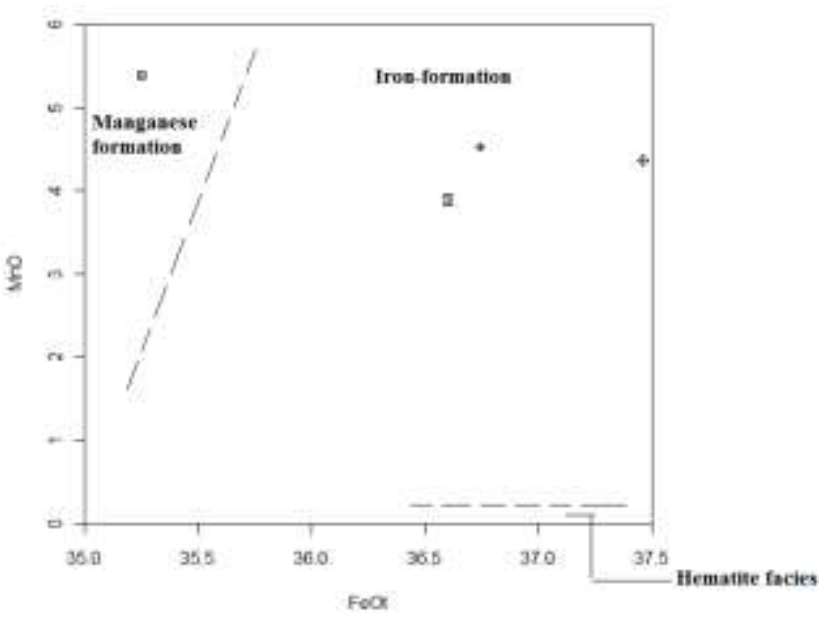

$\oplus$ MA 6(BIF 1) ${ }^{\oplus}$ MA7 (BIF 2),

\section{空 MA8 (BIF3) $\rightarrow$ MA9 (BIF 4)}

Figure 8: $\mathrm{MnO} / \mathrm{FeO}$ (tot)- diagram of the $\mathrm{BIF}$ showing the iron-formation plotting in the hematite facies field with exception of MA9 which could have been the manganese enriched variety.

\section{CONCLUSION}

The Wonaka schist belt is composed of the gneiss (orthogneiss) as the oldest basement rock in to which the supracrustal are formed. The NNE - SSW Pan-African structures found on the gneiss whose foliation is generally $\mathrm{N}-\mathrm{S}$ shows that the obliterating effects of the Pan-African on the previous structures of the rock. This rock could have been Eburnean granite that could have been intruded and metamorphosed during the closing stage of the Eburnean orogeny. On the other hand, geochemistry has shown that the granitic gneiss is an S - Type (paragneiss) which presupposes sedimentary progenitor. This shows that a previous sedimentary deposition, here supposed to be the Birrimian sedimentary cycle, was responsible for the deposition of the protolith. Subsequently, during the Eburnean metamorphic cycle, the gneisses were formed. The amphibolite and the schist have also had similar origin with the granitic gneiss. However differences in metamorphic grades and composition differentiate them. The BIF occurs interbedded with schist and are therefore 
syngenetic. Trace element data have also shown that the BIF is enriched in $\mathrm{Ni}, \mathrm{Cr}, \mathrm{Co}$ and $\mathrm{V}$ this indicates that the BIF have dual provenance, terrigenous and submarine hydrothermal as basic-ultra basic material was a major contributor to the basin of deposition. Geochemical discrimination has also shown that the BIF is a hematite facies type that has affinity to the Lake Superior type BIF. The granodiorites and the granites were intruded during the Pan-African. The sizes of the plutons vary so also their effect on the country rocks. A clearly defined hornfels was formed at the boarders of the Chafe granite intrusion.

\section{ACKNOWLEDGEMENTS}

Contributions from staff of Department of Geology A.B.U Zaria and Kano University of Science and Technology, Wudil is gratefully acknowledged

\section{REFERENCES}

Adekoya, J. A., 1996. The Nigerian Schist belts: Age and depositional environment implications from associated banded iron-formations. Journal Mining and Geology, 32, pp. 27-46.

Ajibade, A. C., Woakes, M. and Rahaman, M. A., 1987. Proterozoic crustal development in the Pan - African regime of Nigeria. American Geophysical Journal, 17: 259 - 271.

Caby, R., 1989. Precambrian terrain of BeninNigeria and Northeast Brazil and the Late Proterozoic South Atlant fit. In: Dalmeyer, R.D. (Ed.), Terranes in the Circum-Atlantic Paleozoic Oregens. Geological Society of America, Special Papers. 230, 145-158.

Dada, S. S., 1999. Geochemistry and petrogenensis of the reworked gneiss complex of North Central Nigeria: Major and trace elements studies on Kaduna amphibolites and migmatite gneisses. Global Journal of Pure and Applied Sciences, 5(4): 535-543.
Dada, S.S., 2008. Proterozoic evolution of the Nigeria-Boborema province, Geological Society London Special publication. 294, 121-136.

Ekwueme, B.N. 2003. The Precambrian geology and evolution of the southeastern Nigerian Basement Complex. pp. 30.

Fitches, W. R., Ajibade, A. C., Egbuniwe, I. G., Holt, R. W., and Wright J. B., (1985). Late Proterozoic Schist belts and plutonism in NM Nigeria. Journal of Geological Society of London, 142: 319-337.

Goki, N.G, Dada, S.S, Oha, A.I. and Moumouni A., 2010. An interpretation of tectonic elements of the Kanke Basement Complex, Central Nigeria. Online Journal of Earth Sciences, 4(2): 89-94

Harper, C.T., Sherrer, G., McCurry, P. and Wright, J.B., 1973. K-Ar retention ages from the Pan-African for Northern Nigeria. Bulletin of Geological Society of America, 84: 919-926.

McCurry, P. 1973. The geology of degree sheet 21, Zaria, Nigeria. Overseas Geology and Mineral Reserves, No. 45.

Mucke, A. 1994. Part 1. Post diagenetic ferruginization and sedimentary rocks (sandstone, oolitic iron stone, kaolins and bauxites) Including comparative study of the reddening of red beds. Developments in Sedimentology, 51, 361 - 395.

Mucke, A. 2005. The Nigerian manganese-rich iron-formations and their host rocks from sedimentation to metamorphism African Journal of Earth Science, 41: 407- 436.

Tarney, J.1977. Petrology, Mineralogy and Geochemistry of the Falkland Plateau Basement Rocks, site 330, deep sea drilling project. Initial Report, 36, 893921.

Trompette, R., 1994. Geology of West Gondwana (2000-500 Ma). PanAfrican Brasilano aggregation of 
South America and Africa. Balkem, Rotterdam - Brookfield.

Turner, D. C., 1983. Upper Proterozoic Schist belts in the Nigerian sector of the Pan

- African Province of West Africa. Precambrian Research 21 (1 - 2): 55 $79,21,55-79$.

Woakes M, Bafor B.E., (1984) Primary gold mineralization in Nigeria. In: GOLD '82: In: Foster RP (ed) The geology, geochemistry and genesis of gold deposits. Geological society of Zimbabwe, special publication, 1: Balkema, Rotterdam, 661-671.
Wright, J. B., Hastings, D. A., Jones, W. B. and Williams, H. R., 1985. Geology and Mineral Resources of West Africa. Allen and Unwin. London. 